\title{
THE EFFECT OF BRAINSTORMING ON EFL READING COMPREHENSION
}

\author{
Tran Thi Ngoc Yen* \\ Vinh University, 182 Le Duan, Vinh, Nghe An, Vietnam
}

Received 27 February 2017

Revised 21 May 2017; Accepted 28 November 2017

\begin{abstract}
This study investigates the effect of brainstorming techniques on EFL learners' reading comprehension. The experiment in this study involved a treatment group and a control group, both of which were following an English course at a language centre in Vietnam. The treatment group were trained in brainstorming techniques during reading lessons whereas the control group were not. Comparisons between the two groups' average scores on pre-test and post-test and their comprehension improvement during the course showed that the treatment group outperformed the control group and thus confirmed that brainstorming has a positive impact on EFL reading comprehension.
\end{abstract}

Keywords: brainstorming, EFL reading, reading comprehension

\section{Introduction}

Brainstorming has been considered an effective method in teaching (Fernald \& Nickolenko, 1993). The principles and rules for using brainstorming techniques in teaching have been discussed in a few studies (Osborn, 1953; Feather, 2004). These techniques allow learners to generate and express their ideas in a systematic way that in turns facilitate the learning process. Yet little research has attempted to examine the benefits that brainstorming techniques may bring to the teaching of specific language skills. Previous research has only focused on how brainstorming works and investigated its relationship with critical thinking. Regarding the teaching of reading skills, although several studies have reported that training in brainstorming facilitates reading comprehension (Richards, 1990; Ghabanchi and Behrooznia, 2014), there is still insufficient data to confirm that this technique can be effectively used as a pre-reading

* Tel.: 84-948287264

Email: yenttn@vinhuni.edu.vn activity. This indicates a need to understand the relationship between brainstorming activities used in reading lessons and EFL learners' comprehension level.

This study intends to examine the impact, if there is any, of brainstorming on EFL learners' reading comprehension in order to provide English language teachers in Vietnam a closer look at the use of brainstorming in teaching the reading skill. This paper first gives a brief overview of reading comprehension. The central idea of this part is that background knowledge is one of the most crucial factors to determine how much the reader understands a text. Based on this, it is suggested that using brainstorming techniques before reading will help readers comprehend the text better since this technique activates readers' background knowledge. The paper also provides review of literature on brainstorming in teaching and learning the reading skill. The second section of the paper is concerned with the methodology used for this study. The third section presents the findings of the research, and the last sections give discussion and conclusions drawn from the study. 


\section{Literature Review}

\subsection{Reading comprehension}

Past research has attempted to analyze the nature of comprehension in reading. Some researchers see it as a process by which readers link and utilize what they know about the world to what they already have as information to get things clear with no misunderstanding (Smith, 2004). While reading, they keep making predictions, or questions based on their theories about the world, and if the questions are answered while or after reading, comprehension is achieved (Smith, 1978). In other words, comprehending is a process of "understanding a written text by extracting the required information from it as effectively as possible" (Grellet, 1981, p.3).

In their attempt to examine what affects EFL reading comprehension, researchers have found that the level of comprehension in reading is dependent on a number of factors. Text factors such as vocabulary (Coady \& Huckin, 1975), genre (Davies, 1995), cohesion (Trimmer, 1995), and syntax (Erickson, 2003), influence the reader's comprehension. Reader factors such as reading purposes (Donoghue, 2009), reading interest (Donoghue, 2009), cultural familiarity (Alptekin, 2006), the reader's prior knowledge (Alexander \& Jetton, 2000) and reading automaticity (Hawkins, 1991) also play a role in deciding how much the reader comprehends a text. Of all these factors, researchers have focused on the reader's prior knowledge (Hailikari et al., 2008). Studies have found that student's background knowledge is crucial in determining how the printed text will be generated during the process of reading. Through schematic representation, readers begin to fine-tune their comprehension as they make connections with their background knowledge and the text at hand (Kang, 2004).

\subsection{Brainstorming for reading}

Reading instructors have used prereading activities as devices to support their L1 readers' interpretation of text and to prevent any possible failure in reading process (Karakas, 2002; Ringler \& Weber, 1984) as these activities can help building new schemata, activating existing schemata, and informing the teacher what the students know. Brainstorming is probably one very popular kind of pre-reading activity (Wallace, 2001). This activity usually involves students' calling out words and concepts that they associate with a key word. Some teachers and instructors have provided their students with a chart of three columns so that the students can write down what they already know about a subject in the first column, indicate what they want to know about the subject in the second column, complete the third column after reading about the subject by writing answers to the questions that they asked in the second column (Ogle's, 1986).

Brainstorming has been seen as a tool that helps L1 readers to activate his prior knowledge and facilitates the reading process (Feather, 2004). This technique enables readers to create and share their prior knowledge to solve problems to reach the goal. While brainstorming, they have to think to generate the ideas from their mind toward the topic that they are going to read, thus bring their storm many different meanings that they have already known about the subject matter of the text (Isaksen, 1998). In addition, brainstorming states a purpose for reading. After recording the brainstormed ideas in a list, readers start reading and verifying whether what was brainstormed is correct or wrong. Thus, they will be reading with a purpose in mind (Feathers, 2004). Brainstorming can also encourage creative thinking and create a working atmosphere (Osborn, 1953). 
Although there has been a consensus that brainstorming, as a pre-reading activity, is an effective technique to activate L1 readers' prior knowledge for reading comprehension, little research has focused on the effect of this technique in EFL reading comprehension. Richards (1990) found that brainstorming helps learners develop their cognitive skills that are necessary for generating and organizing ideas. Along similar lines, Ghabanchi and Behrooznia (2014), Navaee and Asadi (2015) reported that brainstorming has positive effect on learners' reading comprehension.

This study sets out to see if brainstorming facilitates EFL learners' reading comprehension and examines the extent to which it helps them to comprehend the text better.

\section{Research question}

This study aimed to answer the following research question: Do brainstorming techniques help EFL learners to comprehend texts better?

\section{Material and methods}

The participants of the study were Intermediate EFL learners who were following an English course at a language center in Vietnam. Their ages ranged from 19 to 25 at the beginning of the study. Initially, the control group had 25 learners and the treatment group had 23 learners. However, five learners in the control group and three learners in the treatment group dropped class during the experiment time. Therefore, the result analysis only included the data for 20 participants in the control group and 20 participants in the treatment group. All of the participants in the two groups had been studying English for seven years and never had any experience in brainstorming techniques.

In the experiment, both groups followed the English course, which lasted three months and delivered by one and the same teacher.
The course included eight lessons of reading, in which brainstorming was used, eight lessons of speaking, eight lessons of writing and eight lessons of listening. Each lesson lasted 90 minutes and the classes met three times a week.

In each of the lessons for both groups, the teacher did the same procedures, except for the pre-reading stage. For the treatment class, the teacher first provided them with guiding questions, and then let them brainstorm ideas in groups. After that, representatives of the groups reported their groups' opinions and the whole class together collectively arranged ideas into a logical structure. Next, the students were asked to read the text and answer the ten comprehension questions. Finally, the class did some post-reading activities. For the control group, no brainstorming activities were carried out. During the pre-reading stage, the teacher introduced the topic and pre-taught vocabulary. The participants' scores in each of the eight lessons were recorded.

The texts used for the reading lessons for both the control group and treatment group were taken from the textbook named Smart Choice 3 (Wilson \& Boyle, 2010). Each text consisted of approximately 300 words and was written at the intermediate level. Ten comprehension questions were made for each of the texts.

\section{Results}

The participants' reading comprehension ability was measured by counting the number of correct answers out of the 10 multiplechoice comprehension questions for each text. In order to determine whether brainstorming had an effect on reading comprehension, three measurements were made. First, the groups' average scores in the eight sessions were calculated and compared. Second, the groups' average score in the first session was compared with their average score in the last session. 
Third, the groups' average score in the first half of the course was compared with their average score in the second half of the course.

Regarding the average scores in all the eight reading lessons, the results indicated that the treatment group outperformed the control group. As it can be seen in Table 1, the treatment group made an average score of 7.27 points while the control group made an average score of only 5.79. There was a significant difference of 1.48 between the two groups.

Table 1. Mean and standard deviation of comprehension in all lessons for both groups

\begin{tabular}{ccc}
\hline & Treatment group & Control group \\
\hline Mean & 7.27 & 5.79 \\
SD & 0.40 & 0.30 \\
\hline
\end{tabular}

An examination of the scores by each of the participants in the eight lessons showed that the mode of the treatment group's scores was 8 , which repeated 48 times. Meanwhile, for the control group, the mode was 6 and it repeated 63 times. Table 2 presents how many students in each group scored over 7 , under 7, under 6 and under 5 for the whole
Table 2. Numbers of participants falling in each score category for both groups

\begin{tabular}{ccccc}
\hline & $\begin{array}{c}\text { Over } \\
7\end{array}$ & $\begin{array}{c}\text { Over } \\
6\end{array}$ & $\begin{array}{c}\text { Over } \\
5\end{array}$ & $\begin{array}{c}\text { Under } \\
5\end{array}$ \\
\hline $\begin{array}{c}\text { Treatment } \\
\text { group }\end{array}$ & $17 / 20$ & $3 / 20$ & 0 & 0 \\
$\begin{array}{c}\text { Control } \\
\text { group }\end{array}$ & 0 & $6 / 20$ & $14 / 20$ & 0 \\
\hline
\end{tabular}

Altogether, those results show that the use of brainstorming techniques in reading lessons significantly affected the participants' reading comprehension. In other words, the participants trained in brainstorming techniques were more likely to achieve better reading comprehension than those who did not use this kind of technique.

Regarding the comparison between the group's average score on the first session and the last session, the study found that the treatment group made a bigger difference between the first lesson and the last lesson. As shown in Table 3, the treatment group increased their average score by 3.15 points by the end of the course, outperforming the control group, whose average score only increased by 0.90 point.

Table 3. Means and standard deviations of comprehension scores on the first session and the last session for both groups

\begin{tabular}{|c|c|c|c|c|c|c|}
\hline & \multicolumn{3}{|c|}{ Treatment group } & \multicolumn{3}{c|}{ Control group } \\
\hline & First session & Last session & Difference & First session & Last session & Difference \\
\hline Mean & 5.60 & 8.75 & 3.15 & 5.30 & 6.20 & 0.90 \\
\hline SD & 0.68 & 0.44 & 0.81 & 0.47 & 1.00 & 1.11 \\
\hline
\end{tabular}

course. The data indicated that almost all the participants in the treatment group made an average score of over 7 out of 10 while none of the participants in the control group reached this point. Most of them had an average score of over 5 but under 6 .
Table 3 also shows that for the first session, the treatment group and the control group had a similar average score in comprehension with a difference of only 0.30 point between the two groups. This may be explained by the fact that neither group had any experience with brainstorming techniques previously, thus the treatment group, even though trained with this 
technique in the first session, did not outperform the control group. However, after the eight weeks of training, the treatment group made a much bigger increase in
4 , the treatment group made an increase of 2.01 points from the first half to the second half. Meanwhile, the control group made only a slight increase of 0.18 point.

Table 4. Means and standard deviations of comprehension scores on the first session and the last session for both groups

\begin{tabular}{|c|c|c|c|c|c|c|}
\hline & \multicolumn{3}{|c|}{ Treatment group } & \multicolumn{3}{c|}{ Control group } \\
\hline & First half & Second half & Difference & First half & Second half & Difference \\
\hline Mean & 6.38 & 8.16 & 1.78 & 5.65 & 5.93 & 0.28 \\
\hline SD & 0.55 & 0.36 & 0.39 & 0.68 & 0.68 & 0.81 \\
\hline
\end{tabular}

$p<0.05$

comprehension than the control group, and their average score in the last session (8.75) was significantly higher than that of the control group (6.20). An examination into the increases that each of the participants in the two groups made during the course showed that two thirds of the treatment group gained an increase of 3 to 4 points. On the contrary, only one out of the 20 participants in the control group obtained this achievement.

Using one-way ANOVA, we tested the null hypothesis that the mean increases of the two groups were equal. We found that the groups' mean scores were significantly different, $F(1,38)=53.62, p=0.000$. Post hoc comparisons using Tukey HSD test indicated that the mean score for the control group ( $\mathrm{M}=$ $0.90, \mathrm{SD}=1.11$ ) was significantly lower than the mean score for the treatment group ( $\mathrm{M}=$ $3.15, \mathrm{SD}=0.81$ ).

Another way to determine the effect of brainstorming on the participants' reading comprehension was to compare the groups' average score in the first and the second half of the course. This is to eliminate the possibility that some students might have had a good day or bad day on the first day and/or last day of the course, thus having abnormally high scores or low scores, which in turns, distort their results. As can be seen from Table
Using one-way ANOVA, we found that there were significant differences between the control group's mean score and the treatment group's mean score for the first half of the course, $F(1,38)=20.99, p=0.000$ and between the control group's mean score and the treatment group's mean score for the second half of the course, $F(1,38)=34.15$, $p$ $=0.000$.

A one way ANOVA comparing the gain scores (first half to second half) of the two groups results showed the mean scores of the two groups were significantly different, $F(1,38)=52.61, \mathrm{p}=0.000$. The mean comprehension gain score for the treatment group was $1.78(\mathrm{~N}=20, \mathrm{SD}=0.39)$. The mean comprehension gain score for the control group was $0.28(\mathrm{~N}=20, \mathrm{SD}=0.81)$.

Taken together, these results suggested that there was a positive relationship between the use of brainstorming techniques and EFL learners' reading comprehension.

\section{Discussion}

The study set out to determine the effects of brainstorming on EFL learners' reading comprehension. In order to fulfill this purpose, an experiment was carried out. In this experiment, the treatment group and the control group were following an English course, which 
included eight reading lessons. In each of those lessons, both groups had almost the same procedure except that the treatment group was trained in brainstorming techniques before reading the text. Three kinds of measurements were made in order to determine the effect of training in brainstorming techniques. First, the comparison between the groups' average scores for the whole course showed that the treatment group was generally better at comprehending the texts. Second, a comparison between the last session score and the first session score indicated that the treatment group not only did better than the control group during the course, but also increased their comprehension level to a great degree. Third, the comparison between the second half session score and the first half session score showed that the treatment group had a higher score than the control group in both halves of the course, thus reinforcing the reliability of the earlier mentioned results. It can, therefore, be suggested that brainstorming has a positive impact on EFL learners' reading comprehension.

The findings emerging from this experiment enhanced our understanding of the benefits of brainstorming in English language teaching. It seems that this kind of technique promotes reading comprehension to some extent. Most participants in the treatment outperformed the participants in the control group, and they even made significantly bigger increases in reading comprehension over the course. A possible explanation for this may be that their prior knowledge had been activated through brainstorming before they started reading the text. In other words, they were better prepared to enter the texts and therefore comprehended them better. It may also be possible that the brainstorming activities facilitated the participants in this group to generate ideas, organize their thoughts, and helped them be more reflective and creative, which in turn, fostered reading comprehension.

The findings, while preliminary, suggest that EFL teachers should encourage learners to activate their background knowledge by brainstorming before reading texts. This technique seems both mentally and psychologically beneficial. In addition, it can increase learners' motivation to read. Once they have brainstormed about the topic of the text, they will be more enthusiastic to read it and thus enjoy the reading process more. It is, however, advisable for teachers not to impose ideas from the text on learners or criticize the ideas that learners generate as this may demotivate them.

\section{Conclusions}

To conclude, the main goal of the current study was to determine the effect of brainstorming techniques on EFL learners' reading comprehension. The study has shown that training in brainstorming enhances EFL readers' comprehension to a great extent. It was also found that learners who were given chances to use this technique before reading also gradually improved their reading comprehension level through the training time. These findings complement those of earlier studies and suggest that English language teachers should consider designing brainstorming activities for the pre-reading stage in order to boost their students' reading ability.

In future studies, the same procedure can be replicated with a larger sample size to increase the reliability of the results. Researchers can also look at the impact of brainstorming on the development of other language skills. It is possible that brainstorming techniques are a useful strategy in the planning stage of writing for the fact that they facilitate idea generation and creativity. Moreover, since brainstorming establishes a communicative mode of work in the classroom, it may also be that prior 
knowledge activation through brainstorming is a variable affecting speaking and listening skills.

\section{References}

Alexander, Patricia A. \& Jetton, Tamara L. (2000). Learning from text: A multidimensional and developmental perspective. In M. L. Kamil, P. B. Mosenthal, P. D. Pearson, \& R. Barr (Eds.), Handbook of reading research, NJ: Earlbaum.

Alptekin, Cem (2006). Cultural familiarity in inferential and literal comprehension in L2 reading. System, 34, 494-508.

Coady, James \& Huckin, Thomas (1975). Second language vocabulary acquisition. Cambridge: Cambridge University Press.

Davies, Florence (1995). Introducing reading. London: Penguin Group.

Donoghue, Mildred R. (2009). Language arts: Integrating skills for classroom teaching, SAGE Publications, Inc.

Erickson, Karen (2003). Reading comprehension in AAC. The ASHA Leader, 8, 6-9.

Feathers, Karen M. (2004). Info Text: Reading and learning. Toronto: Pippin Publishing Corporation.

Fernald Jr., Loydd W \& Nickolenko, Pam (1993). The creative process: Its use and extent of formalization by corporations. Journal of Creative Behavior, 27(3), 214-220.

Ghabanchi, Jargham \& Behrooznia, Saeedeh (2014). The impact of Brainstorming on Reading Comprehension and Critical Thinking Ability of EFL Learners. Procedia - Social and Behavioral Sciences, 98, 513-521.

Grellet, Francoise (1981). Developing reading skills, Cambridge: Cambridge University Press.

Hailikari, Telle; Katajavuori, Nina \& Lindblom-Ylanne, Sari (2008). The relevance of prior knowledge in learning and instructional design. American Journal of Pharmaceutical Education, 72(5), 1-8.

Hawkins, Black (1991). Teaching children to read in a second language. In M.Celce-Murcia (Ed.), Teaching English as second or foreign language. Boston: Heinle \& Heinle.

Isaksen, Scott G. (1998). A Review of brainstorming research: Six critical issues of inquiry. Creative Problem Solving Group-Buffalo.

Kang, Shumin (2004). Using visual organizers to enhance EFL instruction. JALT Journal, 58, 58-67.

Karakas, Muge (2002). The effects of reading activities on ELT trainee teachers' comprehension of short stories, (Unpublished master's thesis), Canakkale Onsekiz Mart University.

Navaae, Maryam Sari \& Asadi, Masoud (2015). The effects of brainstorming on reading comprehension of Iranian EFL learners. ICT \& Innovations in education - International electronic journal, 3(2), 26-34.

Ogle, Donald M. (1986). K-W-L: A teaching model that develops active reading of expository text. Reading Teacher, Vol. 39, 564-570.

Osborn, Alex Faickney (1953). Applied Imagination: Principles and procedures of creative thinking. New York: Charles Scribner's Sons.

Richards, Jack (1990). New trends in the teaching of writing in ESL/EFL, in Wang Z. (ed.), ELT in China, Papers presented at International Symposium on teaching English in the Chinese context, Foreign Language Teaching and Research Press.

Ringler, Lenore H. \& Weber, Carol K. (1984). A language-thinking approach to reading, San Diego: Harcourt Brace Jovanovich.

Smith, Frank (1978). Reading. Cambridge: Cambridge University Press.

Smith, Frank (2004). Understanding reading. Mahwah: Lawrence Erlbaum Associates, Inc.

Trimmer, Joseph F (1995). Writing with a Purpose. Boston: Houghton Mifflin.

Wallace, Catherine (2001). Reading. Oxford: Oxford University Press.

Wilson, Ken \& Boyle, Mike (2010). Smart choice 3. Oxford: Oxford University Press. 


\title{
ẢNH HƯỞNG CỦA HOẠT ĐộNG ĐộNG NÃO ĐẾN MỨC Độ ĐỌC HIỀU CỦA NGƯỜI HỌC TIẾNG ANH NHƯ MỘT NGOẠI NGƯ⿱
}

\author{
Trần Thị Ngọc Yến \\ Truờng Đại học Vinh, 182 Lê Duẩn, Vinh, NghệAn, Việt Nam
}

Tóm tắt: Nghiên cứu này xem xét giá trị của hoạt động động não đối với mức độ đọc hiểu của người học tiếng Anh như một ngoại ngữ. Trong nghiên cứu này, thí nghiệm được thực hiện trên một nhóm thực nghiệm và một nhóm đối chứng. Cả hai nhóm đều đang theo học một khóa học tiếng Anh ở trung tâm ngoại ngữ ở Việt Nam tại thời điểm thực nghiệm. Nhóm thực nghiệm được học với các hoạt động động não ở các buổi học Đọc còn nhóm đối chứng không được học với các hoạt động này. Các so sánh giữa điểm trung bình của cả hai nhóm ở bài kiểm tra tiền thực nghiệm và sau thực nghiệm cũng như kết quả đọc hiểu trong suốt khóa học cho thấy nhóm thực nghiệm có kết quả tốt hơn nhóm đối chứng. Điều này khẳng định hoạt động động não có ảnh hưởng tích cực tới mức độ đọc hiểu của người học tiếng Anh như một ngoại ngữ.

Tù khóa: hoạt động động não, đọc trong học tiếng Anh như một ngoại ngữ, mức độ đọc hiểu 